\title{
A Study in the Children's Health-Oriented Health Policies After COVID-19 Pandemic Period in Turkey
}

\author{
Türkiye'de COVID-19 Pandemisi Sonrası Dönemde Çocuk Sağlığına Yönelik Sağlık Politikaları \\ Üzerine Bir İnceleme
}

\author{
Özlem DURGUN \\ (D) 0000-0003-1404-2225
} Economics Department of Economics, İstanbul, Turkey
İstanbul University Faculty of

\begin{abstract}
Aim: The coronavirus disease 2019 (COVID-19) pandemic revealed significant negative effects on children and people with disabilities who are classified as socioeconomically disadvantaged groups in addition to individuals in Turkey as in the whole world. Especially, children constitute the most disadvantaged group in families with low socioeconomic status. The situation of these children was analyzed in the study. Also, the performance of health policies for children in COVID-19 pandemic period has been evaluated.

Material and Methods: This study was used in the statistics published in Turkey and in various countries.

Results: Outbreaks are likely to cause significant physical and psychological problems, especially in children. In particular, the medium and long-term effects of being locked up at home on children when their parents have to work are not known in addition to the social distancing that they experience due to the inability of children to come together with their peers. In addition to the deaths in the near and distant environment due to the disease, the fear of getting sick has also a high risk to form negative effects on the psychological development of children. For this reason, to protect the health of future generations, policies implemented for the health of today's children gain importance.

Conclusion: The right to health and education should be universally given to every child. But in developing countries, families cannot provide adequate support to their children for reasons such as unequal income distribution and unemployment. Children are forced to work to support their families when the help of government and institutions is insufficient or cannot be done regularly.
\end{abstract}

Keywords: Health expenditures; epidemic; child development.

\section{ÖZ}

Amaç: Koronavirüs hastalığı 2019 (coronavirus disease 2019, COVID-19) pandemisi tüm dünyada olduğu gibi Türkiye'de de her sosyoekonomik düzeyde birey yanında dezavantajlı kesimler olarak adlandırılan çocuklar ve engelliler üzerinde de önemli olumsuz etkiler ortaya koymuştur. Özellikle çocuklar sosyoekonomik durumu düşük olan ailelerde en dezavantajlı grubu oluşturmaktadır. Çalışmada bu çocukların durumu analiz edilmiştir. Bunun yanında, COVID-19 pandemi döneminde sağlık politikalarında çocuklara yönelik olanlarının performansları da değerlendirilmiştir.

Gereç ve Yöntemler: Bu çalışmada çeşitli ülkelerde ve Türkiye'de yayınlanan istatistiklerden yararlanılmıştır.

Bulgular: Salgınların özellikle çocuklarda önemli fiziksel ve psikolojik sorunlara neden olabilme ihtimali bulunmaktadır. Bilhassa oyun çağındaki çocukların yaşıtları ile bir araya gelememesi nedeniyle yaşadıkları sosyal uzaklaşma yanında, ebeveynleri çalışmak zorundayken evde kilitli kalmanın orta ve uzun vadede ne gibi etkilere yol açacağı henüz bilinmemektedir. Buna ek olarak, hastalık dolayısıyla yakın ve uzak çevrede yaşanan ölümler olması yanında hastalığa yakalanma korkusunun da çocukların psikolojik gelişimleri üzerine olumsuz etkiler yaratma ihtimali oldukça yüksek görünmektedir. Bu nedenle gelecek nesillerin sağlığını korumak amacıyla günümüz çocuklarının sağlığına yönelik uygulanan politikalar önem kazanmaktadır.

Sonuç: Sağlık ve eğitim hakkı evrensel olarak her çocuğa verilmelidir. Ancak gelişmekte olan ülkelerde gelir dağılımındaki bozukluklar, işsizlik gibi nedenlerle aileler çocuklarına yeterli desteği sağlayamamaktadırlar. Devlet ve kurumların yardımları da yeterli gelmediğinde veya düzenli yapılamadığında çocuklar aileye destek olmak için çalışmak zorunda kalmaktadırlar.

Received / Gelis Tarihi : 14.01 Accepted / Kabul Tarihi : 21.03.2021 Available Online /

Çevrimiçi Yayın Tarihi : 25.03.2021
Anahtar kelimeler: Sağlık harcamaları; salgın; çocuk gelişimi. 


\section{INTRODUCTION}

The coronavirus disease 2019 (COVID-19) pandemic harms children's health, social and financial well-being around the globe. Although children are not in a risk category medically, they are significantly affected by the pandemic. The focus of short-term policies is to reduce the risks of physical and psychological effects. However, even before COVID-19 affected the efforts against reducing global poverty, yields of economic growth were unevenly divided in developing economies. Providing access to healthy food and diet; providing emergency care and protection for children; reducing the inaccessibility of education for poor children are still major challenges.

As countries struggle with the pandemic, a rise in health expenditures and economic revitalization continues to be a source of anxiety for countries. These two major concerns have damaged the disadvantaged groups in countries even more, and quarantine measures have aggravated the already existing problems. Income and employment issues amplify the problems in services such as education and health care. While high-income families are less affected by these problems, low-income families are the most affected. Healthcare crises caused by funeral services and not having a health insurance policy are becoming impoverishing health expenditures.

From a purely medical point of view, it appears that children are relatively less affected by COVID-19. However, the economic and social impacts of the pandemic do not affect children equally. The growing inequality caused by the parents creates a permanent gap between advantaged and disadvantaged children in their future lives. As the pandemic spreads all over the world, it changes the daily lives of children. The disease and being stuck indoors caused by it, and the political responses to social distancing affect almost every aspect of the environment in which the children live. Services offered by schools and other organizations, such as education and leisure activities for children, are interrupted by lockdowns. Children are not the faces of this pandemic, but they risk being among the most prominent victims. Children who live in poorer families and neighborhoods, and who are currently in disadvantaged positions, are more likely to suffer further harm from the lockdowns.

Child labor in developing countries arises during poverty when families face financial difficulties. Poverty can be caused by individual shortcomings or by political and economic inequalities. The emergence of poverty can be a deep-rooted situation, but it can also be caused by the sudden illness or the loss of one of the parents. Family is the determinant factor in child labor. Thus, income, life, and employment inequalities should be tracked beforehand, the definition of poverty should be expanded and children's situation should be clarified as well. Although every study is explained with examples, such explanation is not sufficient due to the complex and overlapping reasons of the subject, and the existence of disadvantaged groups in societies still persists.

In this context, the purpose of this paper is to analyze the health policy performance of Turkey regarding children during the COVID-19 pandemic. It is an important field of study to analyze the health policies for disadvantageous groups such as women, children, and elderly people both in the World and in Turkey. We expect to provide a good contribution to the related literature by providing policy performance evaluation towards children in the pandemic period since the negative effects of the pandemic have not been fully understood and suitable policies regarding the outbreak were not yet created. To the best of our knowledge, Denmark is the first country that initiated specific health policies for children during the pandemic period. However, there is not scientific research or an academic paper that evaluated the performances of the health policies for children. Therefore, this paper will be one of the early papers analyzing this subject.

In the first part of the study, the evolution of health expenditures and literature survey is provided. Then, through a detailed analysis of the negative impacts of the pandemic, particularly on vulnerable children, the study will offer alternative policy recommendations to protect the children from the pandemic.

\section{MATERIAL AND METHODS}

This study was used in the statistics published in Turkey and in various countries. The study used open access data based on The Turkish Statistical Institute (TurkStat), International Monetary Fund (IMF) and European Community Statistical Office (EuroStat).

\section{RESULTS}

In this study, health policy and children were examined in Turkey. Outbreaks are likely to cause significant physical and psychological problems, especially in children. In particular, the medium and long-term effects of being locked up at home on children when their parents have to work are not known in addition to the social distancing that they experience due to the inability of children to come together with their peers. In addition to the deaths in the near and distant environment due to the disease, the fear of getting sick has also a high risk to form negative effects on the psychological development of children. For this reason, to protect the health of future generations, policies implemented for the health of today's children gain importance.

\section{The Evolution of Health Expenditures}

The level of health expenditure in a country and how it changes over time depending on a wide variety of demographic, social, and economic factors, as well as the financing arrangements and organization of the health system. Therefore, there are also differences in academic research.

Pre-pandemic health expenditures have been investigated in relation to economic growth. Health expenditures were mostly analyzed by private and public expenditures (1). When the ratio of health expenditures to GDP (an indicator of financial needs of a national healthcare system from a macroeconomic perspective) is studied, it is observed that in many countries health expenditures have increased faster than the GDP in the last 40 years. Public expenditures are of a first priority compared to private expenditures, and they hold an important place (2). Developing countries with limited resources will need to carefully reconsider how to allocate and use their resources more efficiently in the COVID-19 outbreak. Such resource allocation efforts form the basis of quality primary health care for all. They also aim to strengthen the already existing weak systems. 
Studies that estimate the impact of COVID-19 on poverty show that the progress made in the past decade around the world has disappeared and the impact of the pandemic on poverty will be devastating. Limited access to healthcare spending is a factor that can worsen the spread of the virus. Increased health expenditures due to disease and diagnosis, employment without insurance coverage, unemployment, and the risk of disease transmission in low-income groups are areas that make it clear that the health expenditures should be increased. Especially densely populated areas, such as urban slum areas, are places where disease contamination increases. Therefore, preventive health expenses should be made for those living in crowded places. Health spending includes a comprehensive active macroeconomic policy in the form of financial and monetary support for struggling hospitals and healthcare institutions as well as preventive and mitigating health measures (3).

As shown in Figure 1, across the EU countries, per capita health expenditure increased by around $3.0 \%$ each year (adjusted for inflation) between 2013 and 2019, compared to an annual growth rate of only $0.7 \%$ between 2008 and 2013. There are large differences in the amount of health spending in the Euro area (4). There is a strong correlation between income and healthcare expenditures. Among EU member states, expenditure levels in Germany, Austria, Sweden, and the Netherlands are 50\% above the EU average. Romania, Latvia, Bulgaria, and Croatia are among the countries with the lowest expenditure.

Following a period of slow and even negative growth in health expenditure in Europe following the 2008 economic crisis, growth rates are increasing again in almost all countries.

Healthcare expenditure across Europe in 2020 was significantly affected by the COVID-19 outbreak. The development of the crisis has resulted in the rapid transfer of resources to the health sector to improve testing and diagnosis facilities and to increase capacity for treating patients in the health sector. On the other hand, there have been sharp declines in many non-COVID-19 services, such as primary healthcare consultations and nonemergency surgeries.

The discovery of the vaccine and its introduction to the public raises the hopes for the termination of the pandemic, but the uncertainties created by the new waves of the virus on the economy continue. It is estimated that the global economy will grow by $5.5 \%$ in 2021 . In order to achieve this growth, public support will need to continue intensively (5). The improvement in economies varies significantly between countries, depending on the effectiveness of the support brought by the implemented policies, the spread of the pandemic, and other significances that entered the crisis. Evaluating the effects of COVID-19 on societies, economies, and vulnerable groups, it is necessary to be prepared for the problems that will arise during and after the disease as well as the disease itself to get rid of the crisis.

The spread of the COVID-19 pandemic differs between disadvantaged groups in contact with factors such as the lockdown measures, the intensity of the disease, the level of exposure to the psychosocial and socio-economic crises people experience during the pandemic. According to the survey study conducted on 1,066 participants in Bangladesh, poor people feel more insecure due to the increase in the prices of basic needs, the prevention of formal education, and their inability to stock up on food. Those with high income can protect themselves compared to the poor (6). Elders, women, and children are more affected along with the poor as disadvantaged groups during the pandemic process.

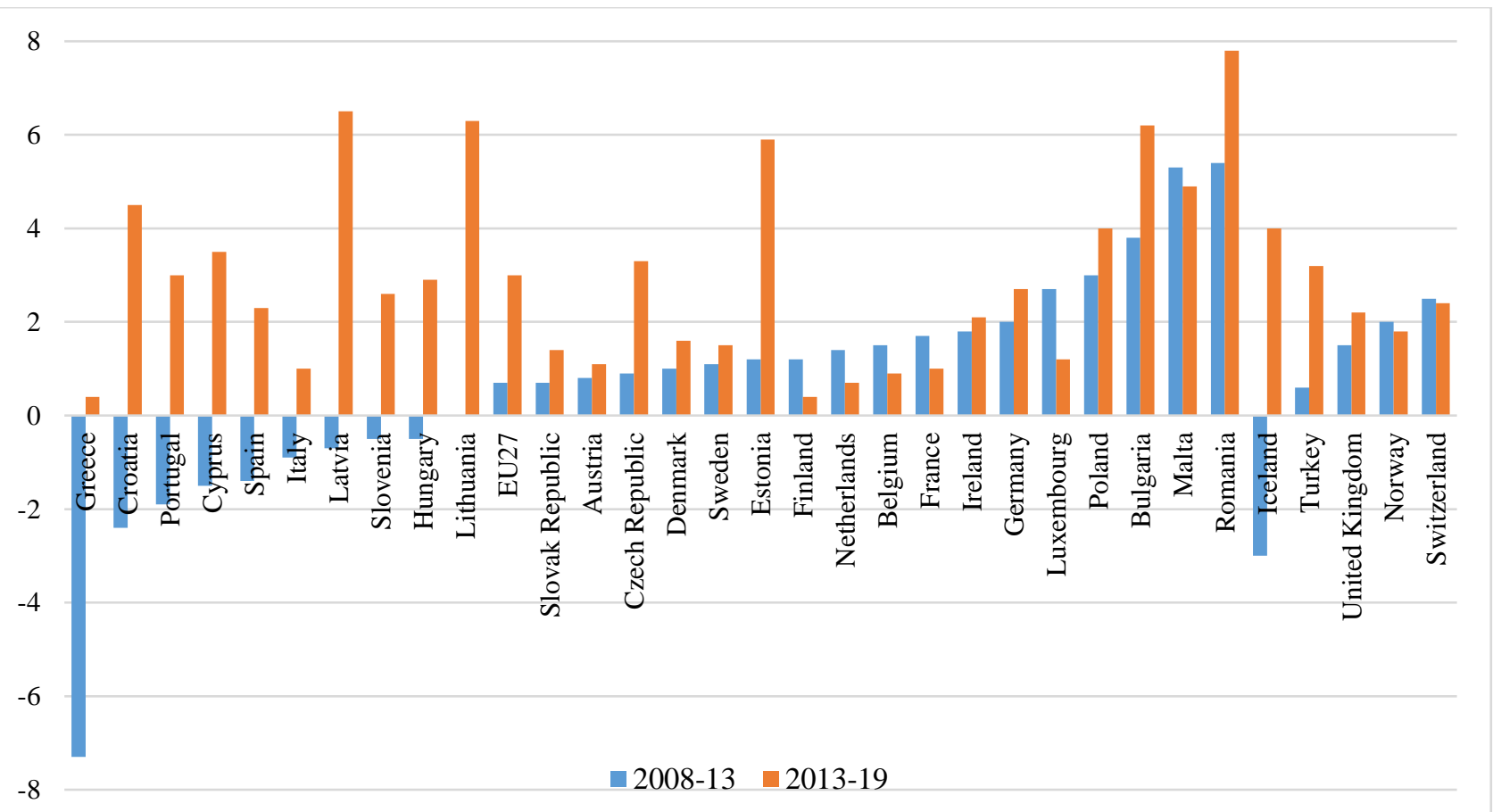

Figure 1. Annual average growth (real terms) in per capita health spending, 2008-19 (or nearest year). Note: The EU average is unweighted. Growth rates and time periods may have been adjusted by the OECD Secretariat to take account of breaks in series. Sources: OECD Health Statistics 2020, Eurostat Database 


\section{Literature Survey}

COVID-19 caused not only great health problems but also large economic losses. Some papers in the literature indicating the economic and social problems as a consequence of the COVID-19 pandemic. Mayer and Lewis (7) investigated different policies applied in different regions. Ceukelaire ve Bodini (8) provided the statistical analysis on patients and deaths. The authors focused on elderly people and explained the economic effects as a consequence of the loss of old patients. Although children represent another disadvantageous group, there is not enough study in the literature addressing the risks they confront, how to cope with the pandemic, and how to educate the families and the children. One of the early study addressing to protect children from pandemic were initiated in 2007 (9). However, this study focused on just the pandemic but how to treat children and how to manage the fragile group of children was not explained. Saxena and Saxena (10) also explained how to protect children from the pandemic. There are also some studies pointing to the violence during the pandemic (11). There is also a limited number of papers on children in Turkey. İşlek (12), Kara (13) and Yorgancioğlu (14) analyzed the policies towards children during the pandemic in Turkey. However, those studies were limited with the explanation of measures chronologically.

\section{The Impact of COVID-19 on Children}

In the first months of the COVID-19 pandemic, lockdown measures reduced the morality rates at an economic cost. It was implemented as going out only for essential needs, closing non-compulsory workplaces, minimizing others' work, and schools turning to online education. More parents had to work from home during the pandemic, and those who were unable to work lost their income. The fact that the effects of the pandemic are versatile and uncertain has led researchers to conduct various research on different topics regarding the COVID-19.

Comparing the effects of the pandemic on health inequalities in line with the Spanish flu pandemic of 1918 and the H1N1 epidemic in 2009, Bambra et al. (15) examined the potential consequences for health inequalities. In another study comparing previous epidemics and pandemics, the controlled and uncontrolled spread of the COVID-19 was examined by comparing it (16). COVID-19 has been found to be a more dangerous disease in comparison with others regarding the rate of spread (17). Due to the rapid transmission of the pandemic and the lockdown measures, there has been an increase in the cases of depression, stress, and anxiety. Since the unemployment rate with the COVID-19 in Australia increased three times more than expected, researchers have examined the relationship between psychological distress and selected health behaviors since the outbreak. Some people have a tendency for social withdrawal or psychological distress associated with the pandemic by participating in negative health behaviors such as smoking or consuming alcohol. It was observed that people with a past of severe depression are more affected by the lockdown and the pandemic. Almost half of the participants reported a decrease in physical activity. Only $20 \%$ had an increase in physical activities. Those with sleep problems also increased by $40 \%$. In Australia, a striking number of $70 \%$ increase in alcohol consumption has been observed (18).
A very small group of 8 children in the UK showed symptoms of COVID-19, but 2 of them tested positive and were treated (19). Although children are largely relieved from the direct health effects of COVID-19 to date, the crisis has a profound effect on the well-being of children. Childhood and adolescence periods are essential stages of human development, where young people develop knowledge and skills to deal with critical aspects of their health, and it is also the first time they experience mental health problems.

The pandemic has significantly disrupted the daily lives of children and adolescents, creating health problems in their adulthood. 188 countries around the world have made schools mandatory, and this decision has affected more than 1.5 billion children and teenagers. Closures of schools, educational institutions, and social activity areas increase the risk of malnutrition, maltreatment, and domestic violence. It is important to acknowledge that the disease outbreak prevention methods will affect some groups of children more than others. These vulnerable groups of children include children living in poverty, children with disabilities, children in out-of-home care, and children at risk of child labor. Moreover, pandemics and measures have the potential to create new vulnerable children (20).

In general, the regions that will affect most of the economic reflections of the pandemic are estimated to be Africa, the Middle East, and South Asia, respectively. It is expected that 80 to $85 \%$ of all people who will be dragged into extreme poverty after the pandemic are going to be Sub-Saharan Africans or South Asians (21). The situation of the poor is similar in developed countries. It is not possible for low-income families to comply with quarantine i.e. not going to work and food stocking. Lowincome jobs such as couriers, cleaning staff, and cooks are occupations that cannot be done remotely. Low-income earners who are less medically insured often work in informal, insecure jobs. It is not possible for these people, who do not have a regular income, to stock up food during the quarantine period. Particularly poor children living in such families experience nutritional problems since the institutions where they are provided daily nutrition are closed. While these children are directed to virtual learning with the closure of the schools, they do not have access to fast internet.

Children from countries with high-income levels, who carry risk factors for health, including smoking, alcohol consumption, illegal drug abuse, unhealthy diet, lack of physical activity, and obesity, were also adversely affected by COVID-19. Quarantine also made them suffer from poverty, lack of education and loss of income, etc. Although alcohol and tobacco control policies have made progress in reducing overall consumption, heavy alcohol consumption continues to be a problem for a significant portion of adolescents and adults. Drug abuse also reaches $15 \%$ among EU country youth. There are large socioeconomic inequalities for most health risk factors. For example, rates of overweight and obesity among children and adolescents are $50 \%$ higher in wealthier families compared to those living in poorer families (22). As an example, children and youth in EU countries have weight problems. On average, one in five adolescents is overweight. Weight problems caused by unhealthy eating 
habits and lack of physical activity are expected to deepen with the closure of schools and quarantine processes.

The COVID-19 is the interruption of the implementation of routine vaccination programs. Families who fear exposure to the new virus implement restrictions that prevent children from getting vaccinated.

\section{The Impact of the Pandemic on Poor Children}

Poor children are more affected by the consequences of the pandemic, with increasing welfare deficits from the past. Children living in poorer households are at increased risk of contracting and transmitting the virus due to underlying health problems, weak immunity systems, and low prevalence of vaccination among children (4). Poor families are less financially robust. They are more fragile against job and earnings losses. Health, sanitation, housing, education are already a major problem in household and child poverty that occurs in poor regions, especially in countries with income inequality. When children are confined to homes due to the pandemic, they cannot participate in distance education nor they can play or study. The most important economic feature of the pandemic crisis is that it reveals structural inequalities worldwide. In economies where only growth prescriptions have been suggested for many years, it does not solve the poverty problem unless the continuity of growth and income distribution is balanced. Unless the income distribution is intervened, the poor are always poor. The income generated as a result of growth is shared among high-income groups. Figure 2 is illustrated: Poverty increases as income inequality increases regionally or globally. In Turkey, one of the countries with the highest income inequality in Europe, the $20 \%$ group with the highest income spends almost half of the total income, and the remaining $80 \%$ of the population spends the remaining 50\% (23).

During the pandemic period, systematic inequalities began to become clearer. For the previous generation, it was possible to find a good job with a living wage once they obtained a high school diploma. There were also income support and social services programs provided for poor people. The involvement of one of the family members in employment was to solve the problem of poverty. However, today, more and more people are unable to find work, even though they are university graduates, and each family member is forced to work in several temporary, contractual, and freelance jobs to earn a living. In Turkey, the global labor force participation rate has increased by about $5 \%$ in the last 5 years.

Employment and economic activity have suffered significantly due to the outbreak. Those who have worked all their lives and suddenly found themselves dependent on reliefs have begun to question their beliefs that having a job is the best social program. Many people have been deprived of any kind of revenue assurance, paid sick leave, or worker protection. This has led to a worldwide catastrophe in the public health crisis.

Figure 3 illustrated that Turkey, Serbia, and Bulgaria share the top three, as they are similar to each other in the distribution of inequality within the European Union when examining those at risk of poverty or social exclusion (24). According to Figure 4 estimates, the global socioeconomic crisis caused by the COVID-19 pandemic will have caused more than 117 million children to grow poor by the end of the year (25).

The harmful effects of the pandemic are not evenly distributed around the world. As it can be seen from the figure above, while the damaging effects occur less in Europe, it increases to the East and reaches its highest form in South Africa. Physical nutrition and mental nutrition, which are important aspects in the development of children, are interrupted by reasons such as families losing their income or parents losing their lives.

Besides, there is a correlation between low-income level and low employment and child abuse (26). Therefore, the expected increase in poverty and decline in employment may negatively affect the children more than the adults. Based on the previous experiences, increasing unemployment of

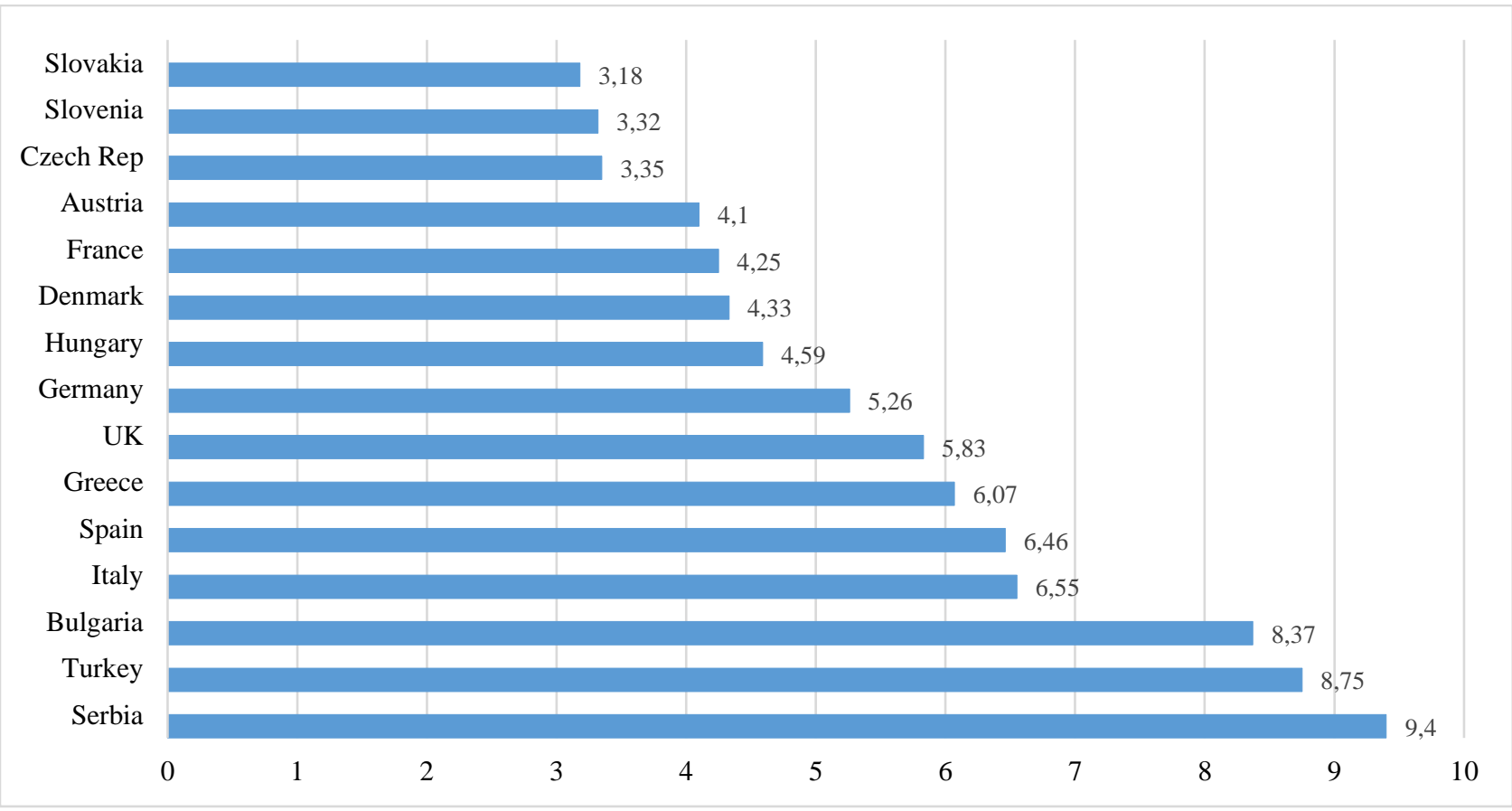

Figure 2. Income distribution inequality P80/P20, the population younger than 65. Source: Eurostat 


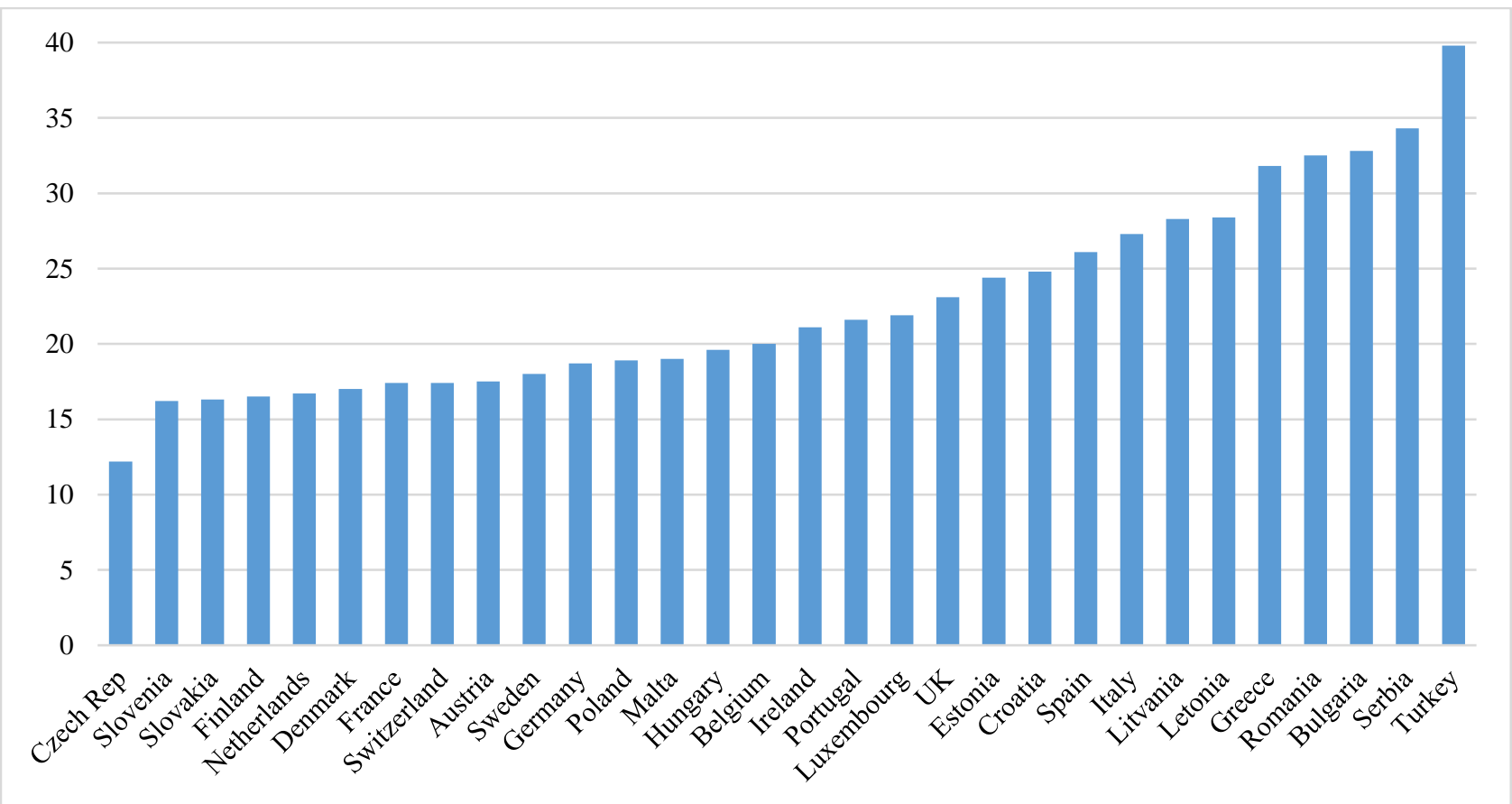

Figure 3. People under the risk of poverty and social exclusion. Source: Eurostat

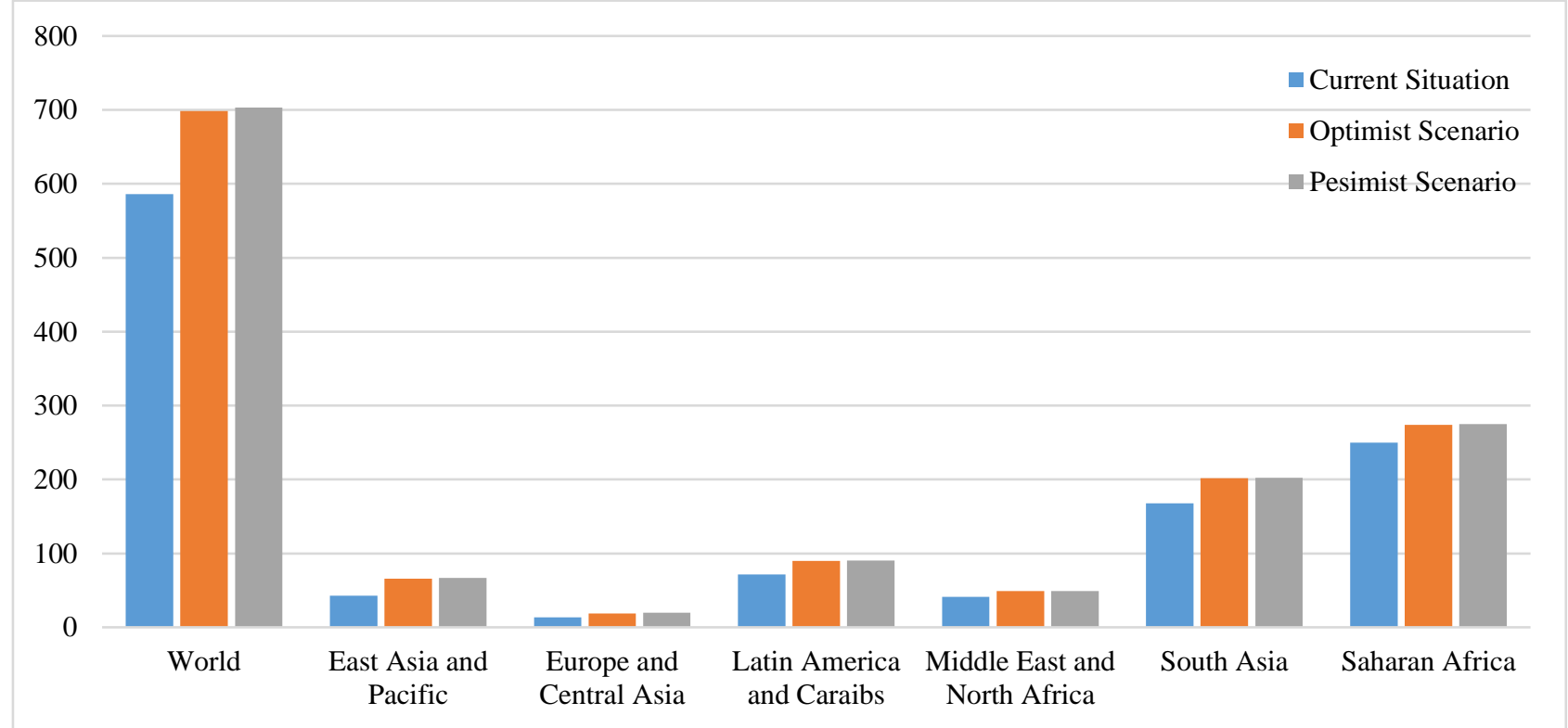

Figure 4. Number of children living in cash-poor households after the outbreak. Source: UNICEF

parents, loss of social security, and refusing the health services due to the pandemic may cause a higher level of physical and psychological violence towards children (27). Risks Faced By Children during the Lockdown

With the spread of the pandemic and the application of containment methods, there is significant uncertainty about the future of the people in the crisis experienced, with the decrease in income with job losses, the allocation of resources to fight the epidemic, and the uncertainty of how the disease will progress. Especially in developing countries, there are commodity crises that interact with problems such as economic crises and employment declines. Even though there are not serious problems in developed countries as much as developing countries, the economy is shrinking in countries such as Japan and
Germany (28). As families lose their income due to COVID-19 and the global economy slides into recession, more households fall into monetary poverty. As of the end of 2020, the crisis caused by the pandemic in developing countries has the possibility of dispatching 142 million more children to financially poor households (25).

Similar to adults, children and teenagers experience stress and depression with the lockdown measures. As the duration and the severity of the lockdown increase, many children experience depression and mental health problems. As children are educated about the importance of a healthy diet and social distance to prevent COVID-19, their anxiety levels increase during this period (29). Many studies have been conducted on anxiety in children, especially in developed countries. Children with problems 
such as ADHD experience increased anxiety and executive dysfunction with the switch to online education. Children experience emotional meltdowns when there is not enough space at home, and when sufficient opportunities are provided at home and the family adapts to the child's rhythm, it is observed that their symptoms lower down (30). Lockdown measures have been applied worldwide to control the transmission of COVID-19. While the quarantine process is conducted to protect people from the disease, external conditions that are threatening or dangerous are taken into account. However, the pandemic is based on the thesis that there are no threats at home and that children are safe in there. However, as Figure 5 states, especially in countries where intense poverty and unfair (31).

Therefore, it is expected that COVID-19 increases the risks of children being exposed to abuse at home and malnutrition, while measures are taken for lockdown reduce children's opportunities to contact their teachers at school and access to the justice system and Child Protection Services (32). Disciplinary penalties involving familial abuse are less common in developed countries. It is applied to children outside the family, especially in schools. Violence in schools is rare. However, it poses problems in many countries. It is more common in rural areas.

Although violence on children is mostly observed in the regions where there are substantial poverty and inequality, it may also be observed in the developed regions. In Canada, every $1 / 3$ of children are threatened with abuse, neglect, and violence within the family. Due to financial problems and hard to reach to subsidies abuse and violence cases are expected to increase during the pandemic in Canada (33).

\section{Effects of the COVID-19 on Children in the Turkey}

One of the expected impacts of the pandemic on children is an increasing number of child labor. According to the results of the 2019 Child Labor Force Survey, 4.4\% (720 thousand children) of children in the age group 5-17 participate in economic activity. Figure 6 illustrates the age groups of working children (34).

While $79.7 \%$ of working children are in the $15-17$ age group, $15.9 \%$ are in the $12-14$ age group and $4.4 \%$ are in the 5-11 age group. Briefly, $20 \%$ of working children are below the age limit of 16 determined by ILO. When the ratio of working children is analyzed by gender, it is seen that $70.6 \%$ of working children are boys and $29.4 \%$ are girls. It should be noted here that young people and children work in developed and high-income countries as well. However, the situation of working children due to poverty or lack of income is of particular importance. While working under healthy conditions in developed countries or wealthy families to support education and develop their skills, it is seen that working children in developing countries are distanced from education due to poverty, work in unhealthy areas, and grow poor. Only a small number of $65.7 \%$ children working in Turkey continue their education. One out of every three working children withdraws from education. Another problem is that $30.8 \%$ of working children are in the agricultural sector, $23.7 \%$ in the industry, and $45.5 \%$ in the service sector (34). As expected, according to ILO (2020) report, child workers are at more risks. The report indicated that there is a great possibility to have worse working conditions and longer working times. Furthermore, since the pandemic negatively affects the parents' employment, there is an increasing tendency to have a higher rate of children workers (35).

With the closure of the services sector with the COVID-19 pandemic, the situation of children who did not attend their education regularly remains vague. Regarding the children coming or brought to the security units (the number has already been increasing over the years) as merely a number is a mistake.

Figure 7 shows that the number of incidents involving children who came or brought to the security units in 2019

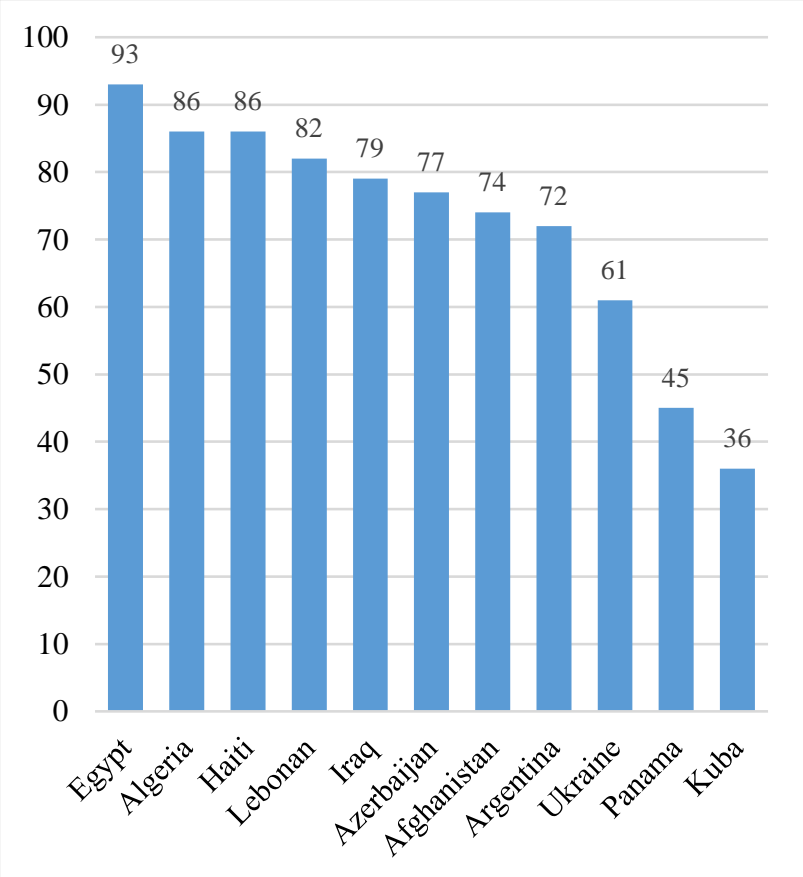

Figure 5. Rates of children that face domestic violence. Source: WHO

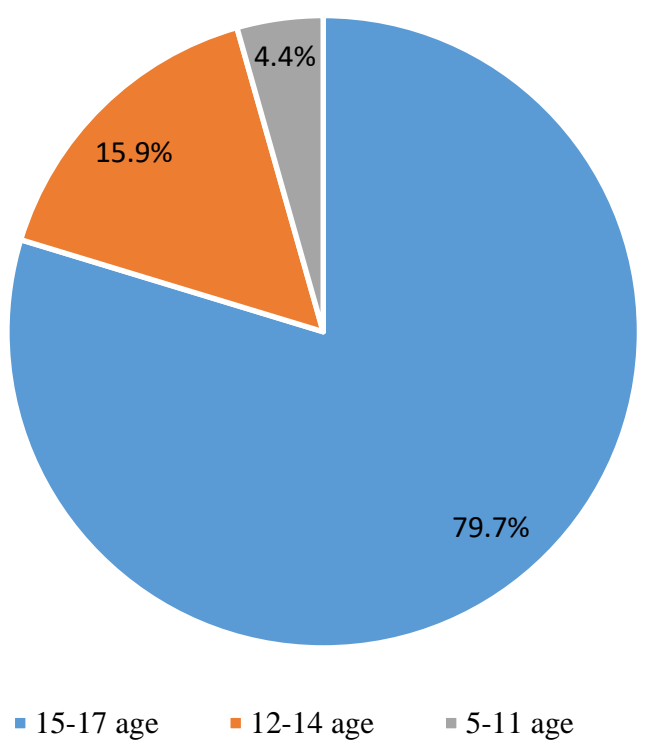

Figure 6. Children working in economic activities. Source: TurkStat 
was 511 thousand 247. In these cases, $46.1 \%$ of the children came to the security units as victims and $32.9 \%$ of them allegedly committed an act defined as a crime in the law (being driven into crime) (34).

If the children dragged into crime are considered as victims because they are actually driven to crime due to poverty and lack of education, lack of family and state support, $80 \%$ of the children come as victims.

Figure 8 clearly shows the increase in the number of child victims. The rapid increase in the number of children dragged into crime is reaching remarkable dimensions (34). The number of incidents involving children increases every year between 5 and $6 \%$. Children driven into crime are involved mostly in injuries. $31.7 \%$ of these children were involved in injuries, $25.6 \%$ committed theft, $8.1 \%$ opposed to the Passport Law, $6.9 \%$ participated in migrant smuggling, $4.6 \%$ interacted with drugs or stimulants (34). Opposition to the passport law and cases of migrant smuggling also point to the existence of children affected by the migration problem. Another type of migration that

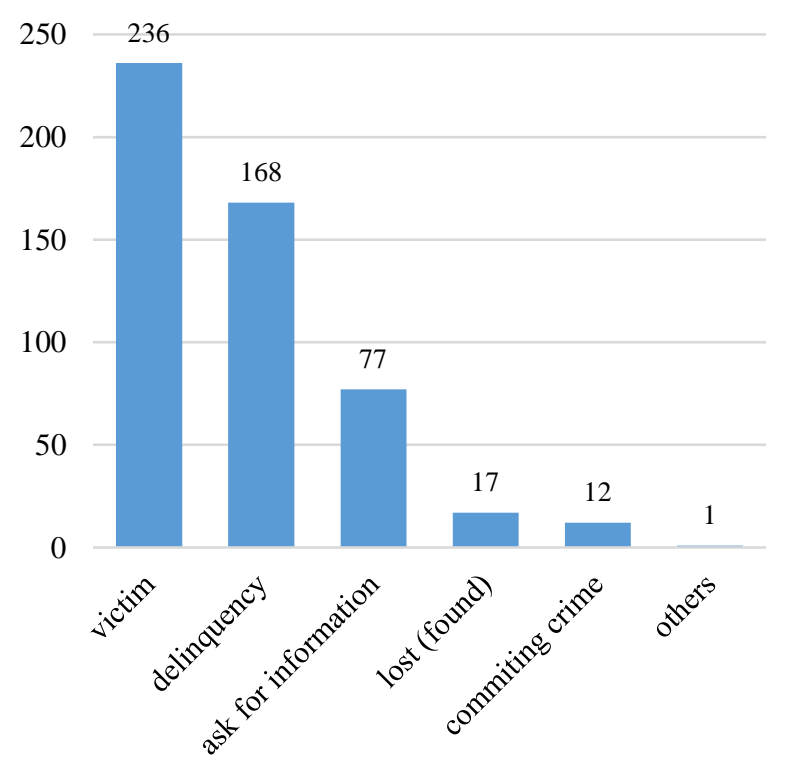

Figure 7. Number of incidence involving children coming to or brought to security unit by reasons. Source: TurkStat

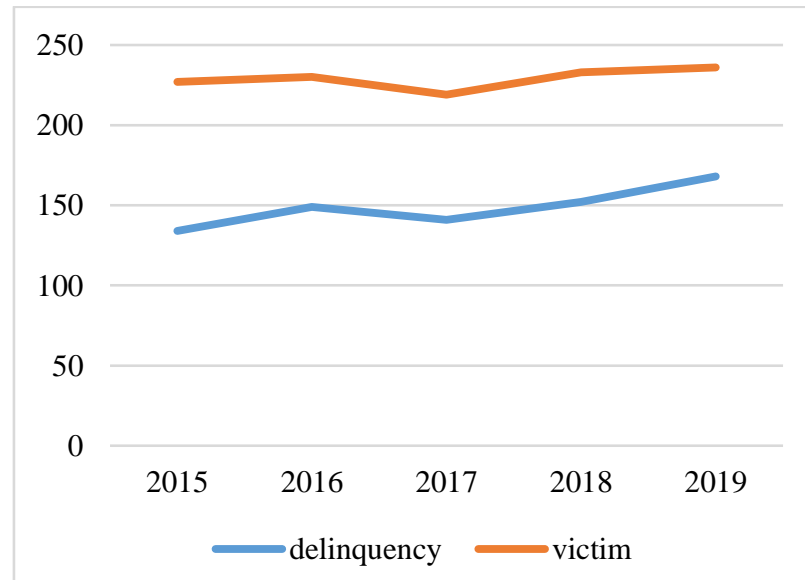

Figure 8. Coming to the security units according to the selected reasons, 2015-2019. Source: TurkStat causes child labor is forced migration. The unsafe environment created by the war has led to the emergence of large migration waves from countries such as Syria, Afghanistan, Iraq to Turkey after 2011 (36). This led to the growth of children's problems and their exclusion from society.

Another problem of the pandemic on children can be a social exclusion. Social exclusion is defined as the partial or complete disappearance of individuals or groups from their society. When the social exclusion problem is evaluated in the context of poverty, the fact that individuals are below the income poverty line cannot even meet their basic needs prevents their existence in social life (37). Families and children cannot bond with other people and get help from their environment. Indeed, the separation of children from their teachers, who are often the first people to notice domestic abuse and report it poses a big problem.

\section{DISCUSSION}

In Turkey, combating the COVID-19 pandemic has led to the isolation of social and economic life and has had significant effects. Important areas of the industry and service sectors have been partially or completely closed. Important economic and social consequences of this closure are also observed. In order to minimize the negative effects of the pandemic, loss assessments should be made frequently. However, sufficient data have not been announced during the outbreak in Turkey. Therefore, in this part, the analysis will be made using limited data. Children make up about a quarter of Turkey's population. This figure 8 was $48.5 \%$ in $1970,41.8 \%$ in 1990 and decreased to $27.5 \%$ in 2019 . According to population projections, the child population rate is predicted to be $27.0 \%$ in $2023,25.6 \%$ in $2030,23.3 \%$ in $2040,20.4 \%$ in 2060 and $19.0 \%$ in 2080 (34). Although its share in the population has decreased, there is a dependency relationship with family income due to the need for care of children who play an important role in the country's development process. It is not possible for children to take care of themselves as adults. For this reason, if the child lives in a poor family, they pass on their poverty to future generations and most likely live poor in the future as well. They raise their children poor. Children's poverty must be prevented to break the cycle (38).

It is easier for individuals and families with regular incomes to escape the cycle of poverty. In social states, they paid special attention to children by following a protective and preventative path for children to read and develop. Their assistance to family and children, the allowances and grants they offer are aimed at building society in a healthy way (39). For this reason, the share allocated to social protection in Turkey has increased rapidly over the years. It increased from 148 billion TL in 2010 to 542 billion TL in 2019. However, the child's share of protection expenses reached only $4.3 \%$ as of 2019 on a family basis. Considering that the share of pensioners and seniors is $48.5 \%$, family/child reliefs remain extremely low (34).

Children of families who cannot earn income because their families cannot work or receive assistance live in poverty. Child labor present in undeveloped countries is also seen in Turkey. Of course, besides having many causes of child labor, these reasons are interrelated. 
As a result of the prevailing COVID-19 pandemic, the problems of children may be worsened. Particularly security, violence, and child abuse may increase during the pandemic as a result of lockdowns. The children who are urged to commit crimes are also victims. As a universal law, the government should protect the children if the child is younger than 18 and cannot be protected by his/her own family. UNICEF points to the increased risk of sexual abuse and violence towards children during pandemics or epidemics. During the lockdown in the 2014-2016 period due to the Ebola virus epidemic, it was observed that there was a higher rate of violence applied to women and school girls. In the same period, the number of child-pregnant increased by twofold (40). Similar findings were observed in developed countries as well. For example, the violence within the families increased by $30 \%$ since the curfew started on March 17th (41). We could not reach the current data in Turkey. However, this may worsen the problems children have to face.

\section{Health Policies Applied in Turkey}

It is hard to control the pandemic because of the difficulty of control, treat and prevention processes. Furthermore, the pandemic is more than a single wave of the event. It brings growing and long-lasting risk as there is more number of cases (42). COVID-19 pandemic has all these features which caused global conflicts and struggles since March 2020 (43). In Turkey, the first COVID-19 case was seen on 11 March 2020. The Ministry of Health first transformed the regular hospitals into pandemic hospitals. In places where there is not pandemic hospitals, patients were isolated in the intensive care units. With the increasing number of patients, all hospitals started to accept COVID-19 infected patients. The citizens who come from different countries were considered expected patients. Therefore, those citizens were kept under quarantine in dormitories. Then international travels were limited. On January 10th, under the coordination of the Ministry of Health, Coronavirus Science Council and Operation Center was found. On March 12th, education was started online at all levels. Starting from March 27th, the daily number of cases were started to be announced (44). Starting from the first day of the pandemic observed in the country, Turkey combatted the pandemic very effectively. Besides, Turkey supported Iran, Italy, and Spain with medical devices and equipment (45).

Health Policies for Elderly People and Other Disadvantageous Groups in Turkey

Unfortunately, the COVID-19 pandemic may be dangerous for elderly people and people with chronic disease. Although the population in Turkey is younger comparing with the European population, the government took immediate precautions for the citizens above 65 . Starting from March 21st, 2020, apart from the chronicle disease people, the citizens above the age of 65 were also limited to go out. However, staying at home for more than one and a half months caused both physical and psychological problems. Therefore, those people were allowed to go out around their community just on Sundays between May 5th, 2020 and June 9th, 2020 (44). Currently, there are still restrictions for elderly people. However, these measures negatively affected the physical and psychological performance of old people above the age of
65. Furthermore, because of these measures, there was a perception of the disease of elderly people (13).

Handicapped people are also considered as another disadvantageous group. Lockdowns prohibited handicapped people from getting regular health services and supports. Besides, as the schools were closed, they could not get proper education, and thus, there were losses in their improvements. For example breaks in the education of autistic children caused great losses in their expected achievements. On the other hand, the health services and supports to handicapped people sometimes caused those people to carry the virus to their families from the crowded health support centers. Besides, the Ministry of Health not only distributed masks and disinfectants but also provided health services at home. Municipalities also provided basic needs. Government entities and NGOs also worked together to support elderly people (14). Finally, the vaccine came to Turkey. The vaccination started from the elderly people who are above 85 and the people who could not go out.

\section{Health Policies for Children in Turkey}

Many health worker unions, NGOs, universities, and related institutions shared information through $\mathrm{TV}$, radio, and other social media channels to inform the families about how to protect themselves and their children from the pandemic in Turkey. Although the children and youngsters are affected less by the pandemic, they can carry the virus to their family members. Right after the first case was detected on March 10th, kindergartens, children's daycare, primary and secondary schools, and high schools were disinfected by the municipalities. Education was interrupted and schools were closed on March 12th. Starting from April 4th, curfew for the youngs under 20 was initiated. On May 5th, it was announced that High Education Entrance Exam would be made at the end of June while it was first announced to be held in July (44). Exams and education models were revised frequently since the process of the pandemic could not be perfectly predicted. Unfortunately, the negative effects and the unexpected side effects of the pandemic on education could not be well-defined and it is still unclear yet. On the 23rd March, distance education and education through the internet started at primary and secondary schools. Ministry of Education initiated an internet-based system "mebozelegitim" for the students who could not get an education via EBA provided by TRT and need to get special education. Similarly, universities also initiated their distance education programs through their distance education centers and Council of Higher Education course platform (12).

Although children are less affected by the pandemic comparing with older people, they have a higher possibility to spread the virus. Thus, the government limited them to go out. It should be noted that even if the children are infected they were kept out of the treatment protocols. Ministry of Family, Working, and Social Services started the full quarantine to the places where the children under government protection stayed in. Those children were allowed to contact their families with the normalization that was started on June 15th. Starting from July 1 st, foster parents' education programs were initiated. On the same date, children were allowed to participate in social, cultural sportive, and camp activities (39). 


\section{Policy Recommendations for the Health Policies for Children in Turkey}

Since the virus is more effective on the elderly people and adults, most of the researches were focused on these group of people and ignored the children. On the contrary, children are the most affected group of age due to natural disasters or pandemics since they are lack social, emotional, behavioral needs and they cannot satisfy these needs without support. Therefore, the policies towards children are urgent and critical. First of all, children may have negative feelings during the lockdown. It is important to know the risk factors. In the near past, the National Health Commission of China announced a guide to protecting their mental health alongside the Daily routine necessities (46). The Turkish government can initiate those policies.

As expressed in the previous parts, there is a higher probability to have more violence and sexual abuse within the family during the pandemic. Thus, the data related to violence, abuse, and other crimes should be announced periodically on the city and regional base. Since there are no reliable data, it is hard to analyze the problem and the scholars can just make estimations based on the studies of other countries. It is a fact that there is an increasing number of children applying the police stations as victims. Because of the personal and occupational problems of consultants, teachers, and pediatricians as well as the politicians who leave distance to these problems, it is hard to reach abused children (47). Therefore, in the US-Florida for example, even though the schools are closed their claims of children abuses. Furthermore, it is estimated that just in March, April and May there are 276.293 unrecorded abuses due to the financial and psychological stress due to the pandemic in the US. In other words, while children are planned to protect from the disease at the expense of loss of education, there are uncounted losses such as abuse and violence at home (48). Parallel to the closing of the schools, there are fewer records of medical reports. Children are also scared of sharing information about their parents by telephone, text message, or emailing. To support this idea, many pieces of research were made before the pandemic period, confirmed that poor support lines and social isolation are perceived as risk factors (49). Social isolation and lockdowns because of the pandemic may cause similar outcomes in Turkey.

Family income is another factor affecting the life standard of children in the pandemic period. The children coming from high-income and well-educated families have a more comfortable living standard than their low-income counterparts. While those children could get enough physical activity, education, and nutrition, the poor children were stuck in small houses, could not get enough nutrition, and could not get quality education due to lack of physical equipment such as a computer, internet, and other necessary tools. Thus, distance education is a great problem for poor children. Furthermore, both the income and academic background of the parents may not be adequate to support those children to get enough distance education. Particularly in families with many children, distance education becomes even more costly since every child needs to have a different computer and technical support. Therefore, while setting the measures for quarantine, the poor conditions of low-income groups should be taken into account.
Another important problem is related to immigrant children. There are many children from Syria, Afghanistan, and other African countries in Turkey. Most of those children are fugitive and they try to survive under miserable conditions. So, the government should take extra precautions for those children to protect and to keep them from infecting their family members.

Girls also represent the most fragile group of children. They are at higher risk of education cuts. Besides, there are higher risks of early marriages for those children. Therefore both within the pandemic process and postpandemic period girls should be monitored.

The last fragile group of children is the children under higher risk of crime. Children whose parents commit crimes are at higher risk of committing the crime. So, those children should be kept away from the criminal environment, and government and other social entities should support those children. If they are not monitored, the pandemic period provides a suitable environment for them to be pushed into the crime.

\section{CONCLUSION}

The right to health and education should be universally given to every child. But in developing countries, families cannot provide adequate support to their children for reasons such as unequal income distribution and unemployment. Children are forced to work to support their families when the help of government and institutions is insufficient or cannot be done regularly. These jobs can also be dangerous and harmful to health in countries where there is no control. Child exploitation, which hinders the development and education of children, is often observed in developing countries.

As a developing country, Turkey is among the most corrupt and poverty-stricken countries among European and OECD countries. Child labor occurs in Turkey due to low health and education spending and intensive migration. Some of these children submit to security units as victims or driven to crime. The services sector, which was closed due to the COVID-19 epidemic, has caused the poor who work most intensively in this sector to lose income. The closure of the services sector, which is the sector where children whose families suffer the loss of income also work the most, has caused a loss of income for children for the second time. Because one in three working children is already away from education, it is not possible for children who are in lockdown due to COVID19 to turn to education since they are not registered. Children grow away from education through the lack of educated families of children who study at home due to the pandemic and problems with access to education such as the lack of equipment like the internet and computers. Families suffering from the loss of income are unable to make the health care costs necessary to protect their children and are unable to reach government support because of the closure of institutions or due to the COVID19 anxiety. Since some of these children are refugees, they are not even registered. Yet, they experience a growing set of problems.

In order to protect children, the state must pay attention to health support as well as educational support. As health spending increases as part of fighting the pandemic, giving up spending in other areas will increase the number of 
children who are abused, forced to work, and not provided with education. There should be regular home-checks along with increased assistance provided to children for their physical and psychological needs caused by the lockdown. Otherwise, problems that are all related to each other will increase child poverty, and in the future, the increase in poverty will affect negatively the development of the country.

Ethics Committee Approval: Since our study was not an experimental study including human or animal subject, ethics committee approval was not required.

Conflict of Interest: None declared by the authors.

Financial Disclosure: None declared by the authors.

Acknowledgements: None declared by the authors.

Author Contributions: Idea/Concept: ÖD; Design: ÖD; Data Collection/Processing: ÖD; Analysis/Interpretation: ÖD; Literature Review: ÖD; Drafting/Writing: ÖD; Critical Review: ÖD.

\section{REFERENCES}

1. Eissa N. Pandemic preparedness and public health expenditure. Economies. 2020;8(3):60.

2. Scherer P, Devaux M. The challenge of financing health care in the current crisis: An analysis based on the OECD data. OECD Health Working Papers. 2010;49. doi: 10.1787/5kmfkgr0nb20-en.

3. Makin AJ, Layton A. The global fiscal response to COVID-19: Risks and repercussions. Econ Anal Policy. 2021;69:340-9.

4. Organisation for Economic Co-operation and Development. Health at a glance 2019: OECD indicators. Paris: OECD Publishing; 2019.

5. imf.org [Internet]. International Monetary Fund. World economic outlook, January 2020, tentative stabilization, sluggish recovery? Available from: https://www.imf.org/en/Publications/WEO/Issues/202 0/01/20/weo-update-january2020.

6. Bodrud-Doza M, Shammi M, Bahlman L, Islam ARMT, Rahman MM. Psychosocial and socioeconomic crisis in Bangladesh due to COVID-19 pandemic: A perception-based assessment. Front Public Health. 2020;8:341

7. Mayer JD, Lewis ND. An inevitable pandemic: geographic insights into the COVID-19 global health emergency. Eurasian Geogr Econ. 2020;61(4-5):404-22.

8. De Ceukelaire W, Bodini C. We need strong public health care to contain the global corona pandemic. Int J Health Serv. 2020;50(3):276-7.

9. Stevenson E, Barrios L, Cordell R, Delozier D, Gorman S, Koenig LJ, Odom E, Polder J, Randolph J, Shimabukuro T, Singleton C. Pandemic influenza planning: addressing the needs of children. Am J Public Health. 2009;99(Suppl 2):S255-60.

10. Saxena R, Saxena SK. Preparing children for pandemics. In: Saxena SK, ed. Coronavirus disease 2019 (COVID-19) epidemiology, pathogenesis, diagnosis, and therapeutics. Singapore: Springer; 2020. p.187-198.
11. Bhatia A, Fabbri C, Cerna-Turoff I, Tanton C, Knight L, Turner E, et al. COVID-19 response measures and violence against children. Bull World Health Organ. 2020;98(9):583-583A.

12. İşlek E, Özatkan Y, Bilir MK, Arı HO, Çelik H, Yıldırım HH. COVID-19 pandemi yönetiminde Türkiye örneği: Sağlık politikası uygulamaları ve stratejileri. Ankara: TÜSPE Yayınları; 2020.

13. Kara E. The function of the social service workforce during the COVID-19 pandemic in disadvantaged groups. Turkish Journal of Social Work Research. 2020;4(1):28-34.

14. Yorgancığlu A. Yaşlılık ve COVID-19. In: İtil O, Altınışık Ergur G, Köktürk N, Havlucu Y, Akgün M, Aykaç N, eds. COVID-19 pandemisi ve sağlığın sosyal bileşenleri. Ankara: Türk Toraks Derneği COVID-19 E-Kitaplar1 Serisi; 2020. p.25-7.

15. Bambra C, Riordan R, Ford J, Matthews F. The COVID-19 pandemic and health inequalities. J Epidemiol Community Health. 2020;74(11):964-8.

16. Marais BJ, Sorrell TC. Pathways to COVID-19 'community protection.' Int J Infect Dis. 2020;96:496-9.

17. Gupta M, Jain R, Taneja S, Chaudhary G, Khari M, Verdú E. Real-time measurement of the uncertain epidemiological appearances of COVID-19 infections. Appl Soft Comput. 2020; [Epub ahead of print]. doi: 10.1016/j.asoc.2020.107039

18. Stanton R, To QG, Khalesi S, Williams SL, Alley SJ, Thwaite TL, et al. Depression, anxiety and stress during COVID-19: Associations with changes in physical activity, sleep, tobacco and alcohol use in Australian adults. Int $\mathbf{J}$ Environ Res Public Health. 2020;17(11):4065.

19. Riphagen S, Gomez X, Gonzalez-Martinez C, Wilkinson N, Theocharis P. Hyperinflammatory shock in children during COVID-19 pandemic. Lancet. 2020;395(10237):1607-8.

20. unicef.org [Internet]. United Nations International Children's Emergency Fund. COVID-19: Children at heightened risk of abuse, neglect, exploitation and violence amidst intensifying containment measures, 2020. Available from: https://www.unicef.org/ guineabissau/press-releases/covid-19-childrenheightened-risk-abuse-neglect-exploitation-andviolence-amidst

21. Sumner A, Hoy C, Ortiz-Juarez E. Estimates of the impact of COVID-19 on global poverty. WIDER Working Paper. 2020;43. doi: 10.35188/UNUWIDER/2020/800-9

22. oecd.org [Internet]. Organisation for Economic Cooperation and Development (OECD). COVID-19: Protecting people and societies. [Cited: 2021 Feb 7]. Available from: https://read.oecd-ilibrary.org/ view/?ref=126_126985-nv145m3196\&title=COVID19-Protecting-people-and-societies

23. ec.europa.eu [Internet]. Eurostat. Income quintile share ratio (S80/S20) by sex. TESSI180. Available from: https://data.europa.eu/euodp/en/data/dataset/y8Mgn2 mKRKGE2tmmfMrOA

24. ec.europa.eu [Internet]. Eurostat. Households statistics on disposable income, saving and investment. Available from: https://ec.europa.eu/eurostat/statisticsexplained/index.php/Households_- 
_statistics_on_disposable_income,_saving_and_invest ment

25. unicef.org [Internet]. United Nations International Children's Emergency Fund. Child poverty. [Cited: 2020 May 16]. Available from: https://www.unicef.org/social-policy/child-poverty

26. Slack KS, Holl JL, Mcdaniel M, Yoo J, Bolger K. Understanding the risks of child neglect: An exploration of poverty and parenting characteristics. Child Maltreat. 2004;9(4):395-408.

27. Rajmil L, Fernandez de Sanmamed MJ, Choonara I, Faresjö T, Hjern A, Kozyrskyj AL, et al. Impact of the 2008 economic and financial crisis on child health: a systematic review. Int $\mathbf{J}$ Environ Res Public Health. 2014;11(6):6528-46.

28. imf.org [Internet]. International Monetary Fund. World economic outlook, April 2020: The great lockdown Available from: https:/www.imf.org/en/Publications/ WEO/Issues/2020/04/14/weo-april-2020.

29. Begum A, Sangeetha S, Sridevi G. Awareness of stress among children during lockdown-a survey. Int J Pharm Res. 2020;12:2082-92.

30. Bobo E, Lin L, Acquaviva E, Caci H, Franc N, Gamon $\mathrm{L}$, et al. How do children and adolescents with Attention Deficit Hyperactivity Disorder (ADHD) experience lockdown during the COVID-19 outbreak? Encephale. 2020;46(3S):S85-S92.

31. United Nations International Children's Emergency Fund. Global overview: Child malnutrition regional trends. UNICEF; 2019.

32. un.org [Internet]. United Nations. Policy brief: The impact of COVID-19 on children, April 2020. Available from: https://unsdg.un.org/resources/policybrief-impact-covid-19-children

33. Kang KT, Jain N. Health care providers must be alert for violence against children during the pandemic. CMAJ. 2020;192(28):E814.

34. tuik.gov.tr [Internet]. Turkish Statistical Institute. Çocuk İstatistikleri. [Cited: 2021 Feb 14]. Available from: https://data.tuik.gov.tr/Bulten/Index?p= Istatistiklerle-Cocuk-2019-33733

35. ilo.org [Internet]. International Labour Organization ILO. COVID-19 impact on child labour and forced labour: The response of the IPEC+Flagship programme, 2020. Available from: https://www.ilo.org/global/ about-the-ilo/how-the-ilo-works/flagships/ipecplus/WCMS_745287/lang--en/index.htm

36. Gül T, Öztürk M. A conceptual study for the reasons of child work. Journal of Süleyman Demirel University Institute of Social Sciences. 2020;37:130-48.

37. Çetin İ. Poverty and poverty indicators: A comparison of Turkey and OECD countries. Ankara Hacı Bayram
Veli University Journal of the Faculty of Economics and Administrative Sciences. 2020;22(2):510-32.

38. Durgun Ö. Gelişmiş ülkelerde çocuk yoksulluğuTeorik ve güncel bir bakış. Ankara: Nobel Yayıncılık; 2019.

39. Erkul E. Sosyal demokrat refah devletlerinde çocuklara yönelik sosyal koruma istatistiklerinin incelenmesi. Çocuk ve Medeniyet. 2020;5(9):137-57.

40. unicef.org [Internet]. United Nations International Children's Emergency Fund. Averting a lost COVID generation, a six-point plan to respond, recover and reimagine a post-pandemic world for every child, 2020. Available from: https://www.unicef.org/reports/averting-lostgeneration-covid19-world-childrens-day-2020-brief

41. Örün H, Topal E. Dünya Sağlık Örgütü, 25. coronavirus-19 (COVID-19) güncellemesi, hassas grupları koruma. Sağlık ve Toplum. 2020;30(Özel Say1):186-8.

42. Vaughan E, Tinker T. Effective health risk communication about pandemic influenza for vulnerable populations. Am J Public Health. 2009;99(Suppl 2):S324-32.

43. who.org [Internet]. World Health Organization. WHO announces COVID-19 outbreak a pandemic, $2020 \mathrm{Mar}$ 12. Available from: https://www.euro.who.int/en/health-topics/healthemergencies/coronavirus-covid19/news/news/2020/3/who-announces-covid-19outbreak-a-pandemic

44. saglik.gov.tr [Internet]. Republic of Turkey Ministry of Health. COVID-19 information page. 2020 Mar 12. Available from: https:/covid19.saglik.gov.tr/

45. Budak F, Korkmaz Ş. An overall evaluation for the COVID-19 pandemic process: The case of Turkey. Journal of Social Research and Management. 2020;1(1):62-79.

46. Akoğlu G, Karaaslan BT. Possible psychosocial effects of the COVID-19 and isolation process on children. Izmir Katip Celebi University Faculty of Health Sciences Journal. 2020;5(2):99-103.

47. Rapoport E, Reisert H, Schoeman E, Adesman A. Reporting of child maltreatment during the SARSCoV-2 pandemic in New York City from March to May 2020. Child Abuse Negl. 2020; [Epub ahead of print]. doi: 10.1016/j.chiabu.2020.104719

48. Baron EJ, Goldstein EG, Wallace CT. Suffering in silence: How COVID-19 school closures inhibit the reporting of child maltreatment. J Public Econ. 2020;190:104258.

49. Moncher FJ. Social isolation and child-abuse risk. Families in Society. 1995;76(7):421-33. 